\title{
THE APPROPRIATE RESPONSE PROCESS (ARP) AND ITS ROLE IN PLANT HEALTH CARE
}

\author{
by John Ball, ${ }^{1}$ John E. Lloyd, ${ }^{2}$ and Daniel F. Marion ${ }^{3}$
}

\begin{abstract}
Plant health care (PHC) is presented as a strategy for the professional care of ornamental landscapes. Plant health care incorporates plant care practices, including integrated pest management (IPM), into a comprehensive management system. This system requires that the practitioner use information about the plant, the stressor, and the client when making management decisions. The appropriate response process (ARP) is introduced as a conceptual model of the PHC decision-making process.
\end{abstract}

Plant health care (PHC) is an integrative plan for establishing and sustaining the long-term performance of plants in managed landscapes. It incorporates landscape design, cultural practices, regular monitoring, and integrated pest management with client input and education. It is applicable to a broad range of tree-related professions and may be performed at many levels of intensity. It applies equally to landscape designers or architects preparing a plan, the contractor installing a landscape, or arborists maintaining an established landscape. However, the practitioner maintaining established landscapes may have a greater variety of investigative and treatment techniques at his or her disposal, particularly when managing high-value, mature trees. Plant health care can be applied by arborists managing residential and commercial properties where the client may be an individual property owner. Plant health care is also applicable in municipal and institutional settings where the client is more broadly defined as the city council or the general public.

\section{PHC LANDSCAPE PROGRAMS}

Plant health care practitioners monitor and maintain landscape plants in conjunction with evaluating the associated environment. In the ornamental landscape, plant management involves maintaining plant performance through cultural practices, investigating the landscape through diligent monitoring, and identifying and treating problems when they do occur. The investigative component of plant health care is performed by an individual known as a moni- tor. In many companies, the monitor may also be involved in sales or other production activities. Few companies currently have an individual who functions solely as a monitor. In addition to inspecting and evaluating plants and stressors, the monitor's other responsibilities may include developing client reports and implementing treatments. Treatments are procedures or actions specific to a particular situation, event, or plant. These may include, but are not limited to, pesticide applications, augmenting or conserving biological control agents of pests, and using structural repair practices such as cabling and bracing. The monitor is not usually responsible for the application of all of these treatments. Generally the monitor's treatment activities are focused on target application of chemical pesticides or the use of biological controls (Marion et al. 1990). Pruning, cabling, and other treatments-while they may be identified by the monitor-are usually applied by a separate crew or company.

In PHC, treatments are initiated when a stressor is detected or anticipated. These treatments may be short-term or ongoing depending on the type, intensity, and duration of the stressor. However, treatments should not be applied merely at the request of a client or as insurance against possible, but insignificant, stressors. Treatments are an integral part of PHC and their intensity can be simple to highly varied and complex.

Many plant problems are related to an improper match of the plant's requirements to the site conditions or to alteration in plant appearance. However, solutions to these types of problems should not be limited to plant removal or client acceptance of the damage. Some problems may demand treatment when the only concern is appearance. The potential defoliation to a client's crabapple from apple scab may not justify treatment from the standpoint of plant vitality, but it may from the standpoint of appearance. The mature crabapple may be the central focal point of the landscape. Plant removal or acceptance of damage is not a realistic option for such a client. People 
receptive to the $\mathrm{PHC}$ approach accept the proper and careful use of chemical pesticides as part of the care of their ornamental landscape (Smith et al. 1995). Plant health care treatments should be well timed and as species and problem specific as possible.

\section{THE QUESTION OF WHEN TO TREAT}

A threshold is defined as a level, point, or value above which something will take place. In insect pest management, this point usually refers to the pest popula tion density that will require intervention. The $\mathrm{PHC}$ concept expands beyond pest management so thresholds related to changes in tree functions, structural integrity, and other stressors may also apply. There are already formulas and thresholds used to assess wood strength loss due to decay (Kennard et al. 1996). However, the primary application of thresholds is within the integrated pest management component of PHC and more specifically, insect pest management. Thresholds for disease pathogens are not easily established and are often intricately related to the degree of associated stressors.

Thresholds have been used in agricultural pest management programs for several decades. Economic injury levels and thresholds are applicable to many crops for which the crop's monetary value with and without pest damage can be calculated. Thresholds are difficult to apply to ornamental landscapes because determining the economic value of damages is far more subjective. Although ornamental landscapes provide many functional benefits-reducing building energy consumption, improving air quality, and reducing noise pollution, among others-aesthetics is still a primary consideration. Thus, associating economic loss with ornamental plant damage is difficult, particularly when only a portion of the plant is affected (ISA 1992).

Aesthetic injury, sometimes referred to as damage or a reduction in plant quality, involves individual perceptions of aesthetics. Limited research has been conducted in this area of ornamental horticulture (Lockshin and Rhodus 1991). However, the research that has been conducted to date has yielded 2 important findings. First, injury is incorrectly perceived by viewers as a dichotomy: damaged or undamaged (Kennard et al. 1996). There is very little intermediate or gray area; either the plant's appearance is acceptable or it is not (Buhyoff and Leuschner 1978).
Second, many people consider as little as 5\% to $10 \%$ defoliation or discoloration as unacceptable damage (Sadof and Raupp 1987; Coffelt and Schultz 1990; Sadof and Alexander 1993). This low threshold assumes that the injury is concentrated and highly visible. A $10 \%$ defoliation uniformly distributed across the canopy is not as easily noticed, nor does it generate the similar concerns as does a $10 \%$ defoliation concentrated in one area of the canopy.

Action thresholds were originally defined as the insect density at which insecticides are applied (Cancelado and Radcliffe 1979). Numerous thresholds have been suggested for ornamental plants. Nielsen (1989) suggested action thresholds, based upon his observations and experience, for several of the more common insects that feed on ornamental plants. However, the total number of thresholds that have been published is very small in comparison to the number of stressors. In addition, national or even regional thresholds are very difficult to establish. A common misconception is that action thresholds are static values. In fact, they are very dynamic. The damage that results from a specific pest density can vary depending upon interaction with other stressors or the plant's current condition. For example, most deciduous trees can withstand partial defoliation, even for several years. However, if a tree has also been under severe moisture stress, the same partial defoliation may result in decline or death.

Action thresholds can also vary with the plant's location in the landscape. If the plant is a focal point, the amount of acceptable damage will be less than if the plant serves a subordinate landscape role. In addition, perception of damage differs among clients. Some will accept more aesthetic damage on plants than others. Thus, a single action threshold is not applicable to all situations.

The major drawback to the use of action thresholds and their associated injury levels is the problem of multiple stressors, which is common in the landscape. Plant damage in the ornamental landscape is usually the result of a stress complex rather than a single causal factor. With the principal exception of defoliation, most damage is the result of several factors. Manion's decline syndrome (1981) conceptually explains the difficulty of managing tree health by solely focusing on insects, mites, and pathogens. The damage may originate with climate or soil factors 
Ball et al.: The Appropriate Response Process in PHC

that predispose the plant to other stressors. These longer-term factors are followed by an inciting stressor, such as frost, that results in severe plant injury. This injury creates accompanying niches for other stressor-contributing factors, generally insects or certain pathogens. While these contributing factors may have established action thresholds, they are often indicators of decline rather than the primary causal agents in the decline. Thus, action thresholds are appropriate primarily where a single biotic stressor and treatment tactic is involved.

Even when thresholds are available, difficulties may arise with the sampling required to reach a treatment decision. The length of time a monitor for a commercial operation spends at a residential property is often 30 minutes or less. This produces great constraints on the monitor who makes an inspection of the landscape plants, provides any necessary treatments, and records actions and observations during that time. Action thresholds designed for tree pests often require sampling multiple plant parts-twigs, leaves, or roots-on multiple plants. Monitors often do not have the time to do the sampling required for some action thresholds. The landscape may also lack the necessary number of plants to complete the sampling.

Most commercial PHC landscape programs provide for monthly or less frequent visits during the growing season. Some companies conduct visits more frequently during the early part of the summer when pest activity is at its highest. Regardless of frequency, the monitor does not have the luxury of sampling a pest population and if the population is below the threshold, of returning the following week to determine if the threshold has been reached. These limitations-the client's low tolerance of injury and monitor time constraints-can result in monitors discarding action thresholds and relying instead upon cover sprays or treating at the mere presence of a pest. The threshold has been reduced from an action threshold based upon correlating pest abundance and plant damage, to a visual threshold, to one determined only by the presence of the pest or the possibility of its occurrence. The constraints that monitors must work within require the use of a more fluid decision-making process.

\section{THE APPROPRIATE RESPONSE PROCESS}

The appropriate response process (ARP) is a model of how PHC practitioners should determine whether a stressor or stress complex requires intervention (Figure 1). The primary purpose of the model is to illustrate the relationship among the 3 critical factors in identifying and managing plant problems: the plant, the stressor(s), and the client(s). The model should not be viewed as a set of instructions or a recipe to be applied in all instances.

Maintenance comprises practices intended to improve or sustain plant health and includes evaluation. The ARP is initiated once a change in the normal condition of the plant is observed or anticipated. This change in condition may be in the plant appearance, physiological function, or structure. How a monitor responds to this change will depend upon 3 important variables: the stressor or stress complex, the plant, and the client. Based upon input from these 3 variables, the monitor will determine the most appropriate response to the specific situation.

The ARP begins with the detection and identification of the key stressors followed by a determination of contributing stressors. Generally, changes in plant condition are due to a stress complex rather than a

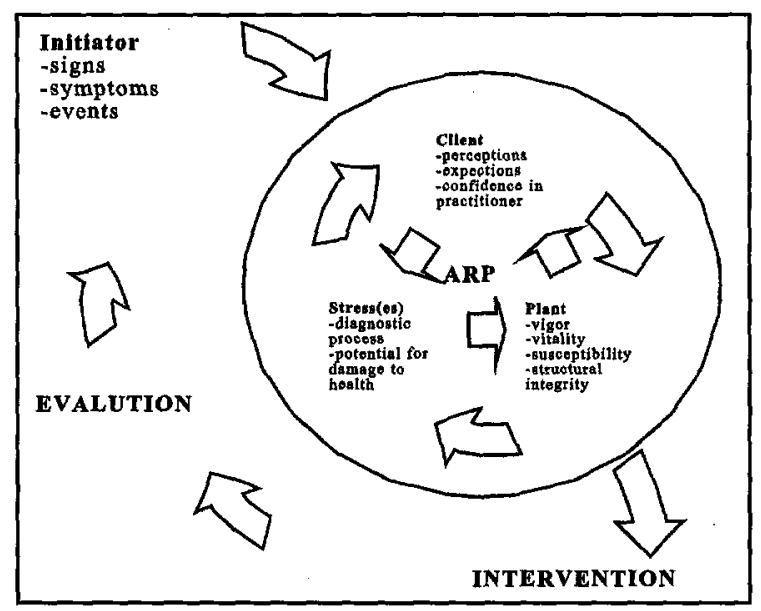

Figure 1. The appropriate response process outlines the procedure to make treatment decisions. The monitor uses plant, stressor, and client information to arrive at the most appropriate response to a particular situation. 
single stress factor. Thus, the monitor must be able to evaluate more than a single biotic or abiotic stressor that is contributing to plant decline. The monitor, working under a time constraint, must be able to thoroughly characterize the symptoms, determine the responsible stressors, and predict future influence of the stressors on the plant's health. The monitor must also assign "weights" to their relative importance. An absolute population density is not essential to the process. However, the monitor must make an assessment of the stressors' potential for unacceptable damage.

For assessments that must be performed quickly, a plant health continuum and classification is presented to broadly and expeditiously help monitors quickly categorize the actions that different classes of damage require (Table 1). This is an outline of the general categories a monitor can include to determine the need for intervention. Insect, mite, or structural thresholds should be incorporated into the process where thresholds are appropriate.

Class 1 is the normal visual condition for the plant. No action is necessary, nor is a treatment or client report. The monitor should be aware that Class 1, however, does not take into account internal conditions or stressors that have not yet become apparent by way of external symptoms.

Class 2 occurs when stressors have resulted in detectable plant injury. Depending upon the intensity of the stressor or the presence of multiple stressors, treatment may or may not be warranted, but client notification is necessary. The client is informed so that he or she is aware that the monitor has taken notice of the event. This reporting is an essential part of the PHC approach. The monitor may then report such damage to the client with the assurance that treatments will be either implemented if the damage is projected to expand (Class 3 ) or continued if the treatment was initiated at Class 2.

The selection of a threshold of $5 \%$ to $10 \%$ damage for Class 3 is based upon the fact that this is the level of damage most people find unacceptable. Aggressive or multiple treatment would be warranted if maintaining the plant's appearance is important. If plant vitality or structure is severely affected (Class 4), then treatments become more complex and are essential to prolong the life or structural integrity of the plant.

Class 5 occurs when the plant's health is beyond the reasonable realm of success for treatment and partial or complete removal is the only option. This classification should not be focused strictly on the plant being evaluated by the monitor at the time. When one plant in a landscape reaches Class 5, adjacent plants in the landscape should be evaluated to determine if the potential for the stressor(s) to threaten these plants exists. If so, then it is the practitioner's responsibility to anticipate those stressors and take appropriate action.

The plant evaluation takes into account available past history of the plant as well as the current site

Table 1. Plant health continuum and actions recommended.

Plant continuum
Class 1. Normal appearance for the plant. No externally
visible plant injury. No significant structural defects present.
Class 2. Minimal (less than $5 \%$ ) visible plant injury
detected or anticipated. The plant injury may take the form
of discolored or wilted leaves, defoliation, or twig dieback
among many other symptoms.

Class 3. Plant injury between $5 \%$ and $10 \%$ is detected or anticipated. Plant injury can take the same forms as Class 2.

Class. 4. Plant vitality or structure is significantly compromised by stressor(s).

Class 5. Plant is in severe decline or a major structural failure has occurred.
Recommended action

Often no action needed, but many stressors do not exhibit external symptoms in the early or mid stages of the disease or disorder

Classify problem as a true threat to health of the plant or simply aesthetic injury. Notify client that injury or stressor has been observed.

Notify client that injury or stressor has been observed. Treatments may be warranted to maintain plant health.

Intense multiple treatments are essential.

Remove portion or whole plant. 
condition. How the plant responds to injury, both internally and visually, is a basic part of ARP. The plant response may vary with the plant part injured, the tissue types affected, the time of injury, and the physiological and environmental influences upon the vitality of the plant. This response information is essential to predicting the potential damage due to the stressor or stress complex. The damage, particularly aesthetic damage, should not be determined without understanding the needs and expectations of the client.

Clients contact arborists and other plant health care practitioners for many reasons. Their primary reasons are the lack of knowledge, time, equipment, or skills to maintain an attractive, vital landscape (Smith et al. 1995). Within this larger need, clients have a broad range of expectations regarding the care of their plants, and misunderstandings can arise easily. It is important that clients be educated as to the scope and severity of the problem. Some will accept minor aesthetic damage if the vitality of the plant is not compromised (Lambur et al. 1982). These clients may expect treatments to be implemented only at Class 3 . Others expect that the appearance of the plants, particularly those near landscape focal points, not be severely impacted and for them Class 2 is the threshold for treatment. How a monitor responds to a change in plant condition is based, in part, upon the client's needs. The monitor must seek to understand the client's needs, and the client must have a basic understanding of the objectives of the PHC program as it relates to the particular tree or landscape. The units of measure for evaluating the service quality must be similar for the client and the monitor. If the client is measuring quality differently from that of the monitor, client dissatisfaction may result.

While expectations of the client are an essential part of the ARP, it does not infer that client initial wishes are always fulfilled. Sometimes clients have unrealistic expectations or are unsure of their own expectations. Surprisingly, there exists a significant minority that expects pests to be eliminated (Ball 1986). Obviously, these and similar expectations must be discussed before the program begins and the potential clients alter their expectations. Generally, practitioners are not faced with this dilemma. However, some unrealistic expectations may exist with many clients, which is why educating clients is essential. Clients may be willing to accept a slightly higher level of aesthetic damage if assured that the vitality of the plant is not compromised.

Based upon these 3 variables, a monitor may elect to intervene, not intervene, or contact the client to further build mutual understanding of the situation. Interventions are any treatments implemented to manage identified stressors or stress complexes. If intervention is deemed necessary by the monitor, the next decision is the extent, degree, and timing of the intervention. Throughout ARP, the monitor's interaction with the client may indicate a minimal intervention in one instance but much more intense and encompassing approach in another.

This decision must also take into account the fact that the next monitoring visit may not be for another month or more. The intervention, if deemed necessary, is implemented with a followup to evaluate its effectiveness. The followup can be conducted as a separate visit or be made during a subsequent monitoring visit.

\section{SUMMARY}

The appropriate response process (ARP) is a description of the process a monitor can use when confronted with a stressor or stress complex. Formal action thresholds are not available for most stressors and are not likely to be soon developed given the time constraints of the monitor and the range in acceptable aesthetic damage. Unfortunately, failure to thoroughly evaluate such stressors can result in inadequate information and poor decisions. The monitor must rely upon his or her comprehensive assessment of the stressor(s), plant, and client-a unique combination-to make appropriate treatment decisions.

\section{LITERATURE CITED}

Ball, J. 1986. Public perception of an integrated pest management program. J. Arboric. 12:135-140.

Buhyoff, G.J., and W.A. Leuschner. 1978. Estimating psychological disutility from damaged forest stands. Forest Sci. 24:424-432.

Cancelado, R.E., and E. B. Radcliffe. 1979. Action thresholds for the potato leafhopper on potatoes in Minnesota. J. Econ. Entomol. 72:566-569.

Coffelt, M.A., and P.B. Schultz. 1990. Development of an aesthetic injury level to decrease pesticide use against orange striped oakworm (Lepidoptera: Saturniidae) in 
an urban pest management project. J. Econ. Entomol. 83:2044-2049.

International Society of Arboriculture (ISA). 1992. Guide for Plant Appraisal. International Society of Arboriculture, Champaign, IL. $103 \mathrm{pp}$.

Kennard, D.K., FE. Putz, and M. Niederhofer. 1996. The predictability of tree decay based on visual assessments. J. Arboric. 22:249-254.

Lambur, M.T., B.O. Parks, FA. Fear, and G.A. Simmons. 1982. Taking public attitudes and practices into account: Pest management in a Michigan suburban community, pp 189-188. In Parks, B.O. (Ed.). Urban and Suburban Trees: Pest Problems, Needs, Prospects, and Solutions. Department of Resource Development, Michigan State University, E.Lansing, MI.

Lockshin, L.S., and WT. Rhodus. 1991. Consumer perceptions of quality: Key issues for horticultural research. HortScience 26:823-825.

Manion, P.D. 1981. Tree Disease Concepts. Prentice-Hall, Englewood Cliffs, NJ. 399 pp.

Marion, D.F, H.G. Larew, J.J. Knodel, and W. Natoli. 1990. Systemic activity of neem extract against the birch leafminer. J. Arboric. 16:12-16.

Nielsen, D.G. 1989. Integrated pest management in arboriculture: From theory to practice. J. Arboric. $15: 25-30$.

Sadof, C.S., and C.M. Alexander. 1993. Limitations of costbenefit-based aesthetic injury levels for managing twospotted spider mites (Acari: Tetranychidae). J. Econ. Entomol. 86:1516-1521.

Sadof, C.S., and M. J. Raupp. 1987. Consumer attitudes toward the defoliation of American arborvitae, Thuja occidentalis, by bagworm, Thyridopteryx ephemeraeformis. J. Environ. Hortic. 5:164-166.

Smith, M.A.L., A.G. Endress, G.R. Smith, R.D. Neely, R.K. Stutman. J.E. Lloyd, J. Ball, K.D. Coder, and T.L. Wadley. 1995. A Guide to the Plant Health Care Management System. (2nd ed.). International Society of Arboriculture, Champaign, IL. 148 pp.

Acknowledgements. The authors would like to express their appreciation to the 2 anonymous reviewers for suggestions and comments on the drafts of our manuscript. We would also like to acknowledge the assistance of Daniel Herms, Ohio Agricultural Research and Development Center, Wooster, Ohio, in the development of the plant health care definition presented in this paper.
${ }^{1}$ Associate Professor of Forestry, Forest Pest Specialist Department of Horticulture and Forestry

Box $2140 \mathrm{~A}$

South Dakota State University

Brookings, SD 57007

${ }^{2}$ Extension Research Associate

Department of Entomology

The Ohio State University

Ohio Agricultural Research and Development Center

Wooster, OH 44691

${ }^{3}$ Professor of Plant Pathology

Department of Environmental Conservation and Horticulture

State University of New York-Finger Lakes

Canandaigua, NY 14424

Résumé. Les soins à la santé des végétaux (en anglais: PHC-Plant Health Care) est une stratégie multidimensionnelle pour l'entretien professionnel des végétaux ornementaux. Cette stratégie incorpore des pratiques d'entretien, incluant la gestion intégrée des insectes et des maladies, dans un système de gestion élaboré. Lune des barrière à l'implantation d'un programme de gestion des insectes et des maladies dans les aménagements paysagers est le manque de seuils définis de décisions. De plus, les praticiens ont rarement le temps ou l'expertise pour mener l'échantillonnage nécessaire afin d'employer les seuils de décision disponibles. Le processus approprié de réponse est introduit sous la forme d'un modèle conceptuel de processus de décision en regard des soins à la santé des végétaux.

Zusammenfassung. Der Pflanzengesundheitsdienst (engl.:PHC) ist eine multidimensionale Strategie der professionellen Pflege von Landschaften mit Naherholungseigenschaften. Der Pflanzengesundheitsdienst vereint verschiedene Pflegepraktiken, einschließlich Integrierten Pflanzenschutz (dt.:IPS) zu einem zusammenfassenden Managementsystem. Ein Hindernis bei der Einführung von IPS in der Landschaftspflege ist der Mangel an etablierten Schwellenwerten. Zusätzlich erschwerend ist, daß die Praktiker selten über die Zeit und das fachwissen verfügen, um die notwendigen 
Voruntersuchungen, die für eine Entscheidung über den Einsatz von Mitteln erforderlich sind, durchzuführen. Der Prozefl zur angemessenen Entscheidungsfindung (engl.: ARP) wird hier als konzeptionelles Modell in den Entscheidungsprozeß innerhalb des IPS eingeführt.

Resumen. El Plan del Cuidado de la Salud de las Plantas (PHC) es una estrategia multidimensional para el cuidado profesional de paisajes ornamentales. El plan incorpora prácticas de cuidado de las plantas, incluyendo el Manejo Integrado de Plagas (IPM), dentro de un sistema de gestión más amplio. Un inconveniente para la ejecución del IPM en paisajes ornamentales es la inexistencia de decisiones de entrada establecidas. Además, los profesionales rara vez tienen el tiempo, o la experiencia, para llevar a cabo el muestreo necesario para emplear las decisiones umbral que estén disponibles. Se introduce el Proceso de Respuesta Apropiada (ARP) como un modelo conceptual del proceso de decisión del PHC. 